\title{
BLEACHING LAWS INTRODUCED ON HALLOWEEN
}

New tooth whitening laws came into effect on 31 October 2012. First and foremost, UK law now officially recognises that tooth whitening is the practice of dentistry. Tooth whitening products containing or releasing between $0.1 \%$ and $6 \%$ hydrogen peroxide are to be sold to dental practitioners only.

Products containing or releasing between $0.1 \%$ and $6 \%$ hydrogen peroxide are legal for tooth whitening, provided that a dentist performs an initial clinical examination and either carries out the first treatment or supervises a suitably qualified dental professional. After this, the dentist can supply the product to the patient so they can complete the cycle of use at home.

Any non-dental professionals performing tooth whitening treatment are liable to be prosecuted. It is the role of the General Dental Council (GDC) to prosecute non-dental professionals who are providing a tooth whitening service, however, Trading Standards can act if the individual or company are using a concentration of (or releasing) over $0.1 \%$ hydrogen peroxide.

The new laws will help to protect patients and give more prominence to the dental professional's role.

www.legislation.gov.uk/ uksi/2012/2263/introduction/made

\section{SIXTY ATTEND INAUGURAL TRAINING EVENT}

Over 60 local and nationally based dental professionals attended the University of Portsmouth Dental Academy's inaugural professional training event on the evening of 27 September 2012.

The event featured a keynote address from Professor Diane Rekow, Dean of King's College Dental Institute and Professor of Orthodontics. Professor Rekow spoke on the scientific advances influencing the direction of dentistry today and the potential challenges and breakthroughs set for the future.

John Weld, Clinical Director of the Dental Academy at the University of
Portsmouth, said: 'This is the beginning of an innovative programme of professional development events being driven by the academic expertise and facilities here at the Dental Academy. I am delighted that so many professionals chose to join us for our first event and listen to a speaker as distinguished as Professor Rekow.'

Visitors also took a tour of the university's world-class facilities which include state-of-the-art clinical education teaching equipment such as the "phantom head' room and a cutting-edge decontamination centre.

\section{DENTISTS ARE FEELING MORE CONFIDENT}

According to a new survey of primary healthcare providers in the UK, confidence amongst dentists has increased by $18 \%$ in the last six months.

The latest Lloyds TSB Commercial Healthcare Confidence Index also found that the number of dentists unwilling to take on NHS work has decreased by a fifth in the last nine months; two-thirds of dentists were not at all confident of the changes to the way NHS dental contracts are funded; and appetite towards future premises ownership has increased by a fifth in the last six months.
Almost all (96\%) of dental practitioners said they were aiming to either retain or increase the number of chairs in their practice over the next five years.

Despite an overall rise in confidence in the last six months, increased financial pressures are set to impact on the dental sector, with over three-quarters $(77 \%)$ of practitioners saying that they expect to see these concerns increase in the next five years.

To take part in the next Healthcare Confidence Index visit www.healthcareconfidenceindex.co.uk. 